\title{
The Effectiveness of Implementing Blended Project Based Learning using ICT- Multimedia in Statistic Learning
}

\author{
Maylita Hasyim* \\ Department of Mathematics Education \\ Universitas Bhinneka PGRI \\ Tulungagung, Indonesia \\ *maylita.hasyim@ubhi.ac.id
}

\author{
Imam Safawi Ahmad \\ Department of Actuary \\ Institut Teknologi Sepuluh Nopember \\ Surabaya, Indonesia \\ safawi@its.ac.id
}

\begin{abstract}
Based on the characteristics of the millennial generation who prefer to do and control what is learned, the role of multimedia learning is very vital in the success of the education of the millennial generation. Learning media with the application of technology have been effective at the tertiary level or adult age who are more literate in technology. This study aimed to analyze the effectiveness of blended project-based learning implementation with ICT-multimedia in terms of statistic learning outcomes. ICT-based learning multimedia was applied to the moodle-based Learning Management System (LMS) developed by Universitas Bhinneka PGRI. This research was a quasi-experimental design with the two groups gender pretest-posttest scenario. There were 31 students of Data Analysis Technique course at Mathematics Education Department participated as subjects. Data was taken from pretest and posttest. The data analysis for comparing learning outcomes used ANOVA method. LMS with ICT-Multimedia showed effective result in improving students' learning outcomes with equality impact both genders, male and female students.
\end{abstract}

Keywords—multimedia, ICT, LMS, ANOVA, learning outcome

\section{INTRODUCTION}

The millennial generations in the era of technology disruption 4.0 have very unique characteristics of learning. They prefer doing and controlling over what is being learned by themselves. Based on the characteristics of these learners, the role of multimedia learning is very vital in the educational success of the millennial generations. Based on its terminology, the definition of "multimedia" is a combination form of various media such as images, text, animation, sound, video or others that are integrated and synergistic through computer programs or other electronic devices for the achievement of certain goals [1]. Thus, to meet these needs, the use of multimedia in learning is such a good alternative for optimal and impressive learning [2]. The learning process by utilizing technology is a necessity in today's internet era. Educational technology is the study and ethical practice of facilitating learning and improving performance by creating, using and managing appropriate technological processes and resources [3]. Learning media with the application of technology have been effective at the tertiary level or adult age who are more literate in technology. Boghikian-Whitby and Mortagy, suggest that adult students benefit more from taking online classes compared to traditional age students, and that computer competency helped improve performance in online classes over time [4].

One of the interactive learning multimedia is e-learning (electronic learning), which is a learning medium that is presented electronically and computer-based media [5]. Elearning which is currently being developed is in the form of a Learning Management System (LMS), where one of the widely used and open-source licensed forms of LMS is moodle (Modular Object-Oriented Dynamic Learning Environment). Moodle is defined as software that has been produced to assist internet and web-based learning activities with the principles of social constructionist pedagogy [6]. Universitas Bhinneka PGRI (transformation from STKIP PGRI Tulungagung) already has a moodle-based LMS with the address https://vlearn.ubhi.ac.id/ with the homepage view presented in Figure 1.

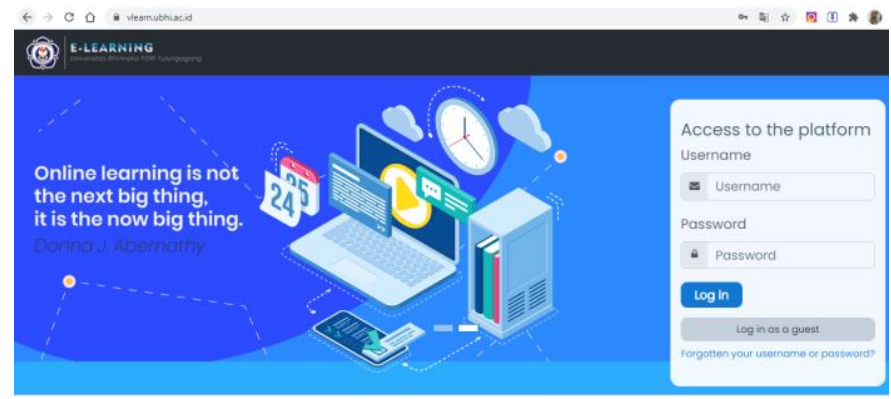

Fig. 1. The homepage of Universitas Bhinneka PGRI learning management system.

Universitas Bhinneka PGRI Learning Management System is used as an ICT-based learning media by both lecturers and students. The effort to improve the quality of learning through the development of multimedia learning presented in the LMS 
is the idea or basis for conducting this study in Mathematics Education Department at Universitas Bhinneka PGRI.

In this study, multimedia ICT-based learning was used in the Blended Project Based Learning model, where the learning orientation emphasized the projects given to students through virtual (online) learning combined with the theory conveyed during face-to-face learning. Blended learning was a new concept in learning where the delivery of materials could be done in class and online [7]. The notion of blended learning is combining the advantages of e-learning, face-to-face advantages, and practice [7]. Furthermore, Graham mentions that blended learning is a learning which combines learning media, learning models, learning theories, face-to-face learning, and online learning [8]. Based on the explanation above, it can be concluded that blended learning is a learning which combines e-learning with face-to-face learning using learning media and learning theories in its learning process.

Project-based learning as a learning model provides opportunities for lecturers to manage classroom learning by involving project work. Project work is a form of work that contains complex tasks based on challenging questions and problems, and requires students to design, solve problems, make decisions, carry out investigative activities, and provide opportunities for students to work independently [9]. Thus, project-based learning is more student-centered because students are required to collect and integrate new knowledge. This new knowledge is obtained from the results of student projects assisted by lecturers, in which the role of the lecturer in this learning is as a facilitator [9].

This study applied a learning concept that combined blended learning with project-based learning, which meant that project-based learning was packaged face-to-face and online through LMS media. This learning model was called the "Blended Project Based Learning Model", which was expected to provide opportunities for students to improve their higher order thinking skills (HOTS). The use of information technology in the development of multimedia learning was expected to be a product of innovation in the field of education and learning, especially at Universitas Bhinneka PGRI which was in accordance with the characteristics of students as the millennial generations.

Various previous studies applying ICT-based learning multimedia were used as references in this study, such as: Sari [2] examining the use of multimedia to support the quality of learning; Febrianto et al., [10] analyzing the application of Prezi learning media to the learning outcomes of class X TPHP students in the subject of quality control in processing at SMK Negeri 3 Takalar; Murray et al., [11] applying a learning management system based learning model with Moodle software development in Senior High School in Yogyakarta; and Muhammad and Priatna [12] using a Learning Management System (LMS) in higher education: A Case Study at the Indonesia University of Education.

Other previous studies implementing Blended Project based Learning which used as references in this study were: studying
Blended Learning, the 21st Century Learning Model in higher education [2,8]; and developing a tourism geography module with project based learning for coastal and marine ecotourism materials in undergraduate of Geography Education Study Program, State University of Malang [9].

The preliminary study that had been carried out by researchers was to develop ICT-based learning media for the Mathematics Statistics I course based on online learning on the LMS of Universitas Bhinneka PGRI which had been conducted in 2019. This preliminary study collaborated with Kanjuruhan University of Malang in the implementation of online learning. Based on the results of this preliminary study, it was concluded that this research should be conducted as a learning innovation for students of the Universitas Bhinneka PGRI especially in Mathematics Education Department in order to improve students' learning achievement. Previous research had developed ICT-based learning multimedia in LMS in the Data Analysis Technique course [5].

Learning model with e-learning has become a strategic issue in the international realm for the last few decades. The effectiveness of this method was measured and reviewed by various parties who were concerned in the field of learning technology, and compared with traditional methods. Noesgaard and Ørngreen discusses whether e-Learning and traditional face-to-face learning should be measured according to the same definitions of and approaches to effectiveness [13]. Therefore we need a measurement to evaluate the use of learning technology, in this case is all about its effectiveness. The evaluation of the effectiveness of new multimedia technologies in classroom environment is really needed in term of their contribution to the improvement of teaching and learning [14].

Referring to the results of preliminary studies and previous studies, this study aimed to analyze the effectiveness of the Blended Project Based Learning implementation using ICTbased multimedia learning in Data Analysis Technique (Analis Teknik Data) course LMS in terms of the students' learning outcomes. The results of this study could be used as a reference in developing interactive multimedia learning to increase students' activity and learning outcomes.

\section{METHODS}

This study used a quasi-experimental design with factorial design. This design allowed a moderator variable that affected the relationship between the independent and dependent variables, the $2 \times 2$ factorial design is shown in Table 1 below:

TABLE I. $2 \times 2$ FACTORIAL DESIGN

\begin{tabular}{|l|l|l|l|}
\hline \multirow{2}{*}{ Model and Media } & \multicolumn{2}{|c|}{ Gender } & \multirow{2}{*}{ Total } \\
\cline { 2 - 3 } & \multicolumn{1}{|c|}{ Male (1) } & Female (2) & $\mathrm{A}_{1}$ \\
\hline $\begin{array}{l}\text { PjBL - without media } \\
(1)\end{array}$ & $\mathrm{a}_{1} \mathrm{~b}_{1}$ & $\mathrm{a}_{1} \mathrm{~b}_{2}$ & $\mathrm{~A}_{2}$ \\
\hline $\begin{array}{l}\text { Blended PjBL - ICT- } \\
\text { Based multimedia (2) }\end{array}$ & $\mathrm{a}_{2} \mathrm{~b}_{1}$ & $\mathrm{a}_{2} \mathrm{~b}_{2}$ & $\mathrm{G}$ \\
\hline Total & $\mathrm{B}_{1}$ & $\mathrm{~B}_{2}$ & \\
\hline
\end{tabular}


Based on Table 1, the research variables consisted of:

- Independent variables:

- Learning model, nominal scale with two categories, namely: category 1 for $\mathrm{PjBL}$ without media and category 2 for Blended PjBL with ICTbased multimedia.

- Gender, nominal scale with two categories, they were category 1 for male and category 2 for female

- The dependent variable (Y) was the students' scores of Data Analysis Technique course in the even semester in the academic year of $2019 / 2020$

The population in this study were all students of Mathematics Education Department, Universitas Bhinneka PGRI which consisted of 134 students. In this study, the sampling technique used was cluster random sampling which finally gained 1 class from $5 \mathrm{~A}$ class with 31 students as the experimental class.

The research instrument used was the pre-test questions with the learning method divided into PjBL learning without media (1) and post-test using the ICT-based PjBL Multimedia method (2). The most common way to measure effectiveness was quantitatively with pre- and post-tests [13]. Before the instrument was given, the content validity and reliability tests were carried out. The data analysis technique used was descriptive statistics, prerequisite tests and hypothesis testing. The prerequisite test used was the Liliefors type normality test and the F test homogeneity test and Bartlett test. To test the hypothesis, researchers used data analysis techniques with twoway analysis of variance (ANOVA) with interaction with a significant level of $\alpha=0.05$ or $5 \%$. After it had been known that there was an interaction among the independent variables and the dependent variable, then it was continued with the Tukey test.

\section{RESULTS AND DISCUSSION}

The data obtained in this study were the students score of Data Analysis Technique course in the even semester in the academic year of 2019/2020 which used the PjBL learning model without media and ICT-based multimedia PjBL. Based on the results of data analysis, the prerequisite test had been fulfilled both the normality test and the homogeneity test. The normality test used the Liliefors test. The results of the normality test in the experimental class obtained $L_{\mathrm{value}}=0.113$, where $L_{\text {value }}<$ table so that the data $H 0$ was accepted and the data were normally distributed. The homogeneity test used the F test for data on test results between models with $F_{\text {value }}=1.359$ and $F_{\text {table }}=2.205 . F_{\text {value }}<F_{\text {table }}$ so that $H 0$ was accepted and the population variance was homogeneous. The Bartlett test for data between the gender categories of students obtained $\chi^{2}$ value $=3.238$. The value of $\mathcal{X}_{\text {value }}^{2}<\mathcal{X}_{\text {table }}^{2}$ so that $H 0$ was accepted and the population variance was homogeneous.

\section{Hypothesis test results:}

- Two-way analysis of variance between the learning model of learning methods and gender obtained $\mathrm{F}_{\text {value }}=$ 6,587 and $\mathrm{F}_{\text {table }}=. \mathrm{F}_{\text {value }}>\mathrm{F}_{\text {table }}$ and the decision $\mathrm{H} 0 \mathrm{~A}$ (null hypothesis between lines) was rejected;

- The results of the analysis of the inter-column variance analysis hypothesis test or the calculation of gender obtained that the HOB decision (null hypothesis between columns) was accepted. Separating the sex (gender) of students in this study did not affect their ability to solve questions.

- When using the PjBL learning model without media or when the ICT-based multimedia PjBL learning model was being implemented, it gave results which were not different on the average for all students. The assumption of differences in technology capabilities between genders was not proven in this case;

- The results of the inter-cell variance analysis hypothesis test which meant the calculation of the interaction between PjBL learning methods without media and ICT-based multimedia PjBL with the student's gender toward the ability to work on questions of Data Analysis Technique course obtained the null hypothesis between lines was accepted.

The results of the post-ANOVA test between rows obtained the mean significance between rows 1 and 2 , so it could be concluded that the ICT-based multimedia PjBL learning method was able to increase the score in the Data Analysis Technique course. Researchers assumed that the PjBL learning model without media and ICT-based multimedia PjBL gave an equal effect to each student in the class on the ability of doing the Midterm Test in Data Analysis Technique course. This was in line with the research which stated that PjBL had a positive influence on the problem-solving ability of Data Analysis Techniques course. The two models had an effect on the ability to solve Midterm Test questions in Data Analysis Technique course.

The use of multimedia in classroom learning using devices with more effective results for students was also emphasized by the research of $\mathrm{Li}$ and Kang [7]. The application of multimedia devices to classroom teaching helped enlarge the amount of classroom information, enrich teaching content, enhance interaction between teacher and student, increase teachers' personal competence and capacity for information, and as a result, it also helped teachers achieve the goal of remarkably promoting teaching effectiveness in the classroom [15].

Technological developments have an impact on the way of teachers and students perceive learning. So that the use of technological devices in innovation of learning tools development is very important. The integration multimedia technology and this has led a new paradigm in education and the evolution of new concepts in content development and a 
number of innovative methods in which information can be communicated to the learner [16].

The use of multimedia learning supported by adequate tools will be the key to the advancement of education in the future. The development of technology information and its continuously improved capacity will greatly assist teachers and students in achieving optimal levels of educational effectiveness. So that the effectiveness of learning can be improved. Multimedia data will play an even greater role in the future of computer-supported education than it already does. Teaching and learning is an activity which naturally involves different modalities. The new devices and advancements in technology improve signal processing possibilities [17]. Effective learning media are expected to increase deep interaction between teachers and students. Multimedia technology empowers the educational process by means of increased interaction between teachers and the students [18].

\section{CONCLUSION}

The results of the data analysis showed that the implementation of the Blended Project Based Learning model using ICT-based multimedia learning was effective. It improved the students' learning outcomes with the same impact on male and female students who took Data Analysis Technique course in Mathematics Education Department at Universitas Bhinneka PGRI. Suggestions for further researchers focus on the development of learning models that are more appropriate to the application of online learning. Furthermore, it can add new insights and information about the use of learning models combined with schoology-based elearning on mathematical problem solving abilities in terms of student's self-efficacy levels.

\section{ACKNOWLEDGMENT}

Thanks to Universitas Bhinneka PGRI for providing research grant so that this research could be conducted successfully based on the target of researchers.

\section{REFERENCES}

[1] W.A. Surasmi, "Pemanfaatan Multimedia Untuk Mendukung Kualitas Pembelajaran," Prosiding Temu Ilmiah Nasional Guru (TING) VIII, Universitas Terbuka, 2016.

[2] M. Sari, "Blended Learning, Model Pembelajaran Abad Ke-21 Di Perguruan Tinggi," Ta'dib, Jurnal Fakultas Pendidikan Dan Pelatihan Guru, Universitas Batusangkar, vol. 17, pp. 126-136, 2016.
[3] S.S.N. Ørngreen and R. Rikke, "The Effectiveness of E-Learning: An Explorative and Integrative Review of the Definitions, Methodologies and Factors that Promote e-Learning Effectiveness," Electronic Journal of E-Learning, vol. 13, 2015.

[4] S. Boghikian-Whitby and Y. Mortagy, "The effect of studen background in e-Learning-Longitudinal study," Issues in Informing Science \& Information Technology, vol. 5, pp. 107-126, 2008.

[5] H. Husamah, Pembelajaran Bauran (Blended Learning) Terampil Memadukan Keunggulan Pembelajaran Face-To-Face, E-learning OfineOnline, dan Mobile Learning. Jakarta: Prestasi Pustaka, 2014.

[6] H. Almara'beh, E.F. Amer, and A. Sulieman, "The effectiveness of multimedia learning tools in education," International Journal, vol. 5, 2015.

[7] J. Li and M. Kang, "Using Multimedia to Promote Teaching Effectiveness in the Classroom of China," International Conference on on Soft Computing in Information Communication Technology (SCICT), 2014

[8] S. Raharja, P.L. Diat, and N.A. Agung, "Model Pembelajaran Berbasis Learning Management System Dengan Pengembangan Software Moodle Di SMA Negeri Kota Yogyakarta,” Jurnal Kependidikan, vol. 41, pp. 55-70, 2011.

[9] H.D. Surjono, Multimedia Pembelajaran Interaktif, Konsep dan Pengembangan. Yogyakarta: UNY Press, 2017.

[10] F. Febrianto, M. Rais, and N. Nurmila, "Analisis Penerapan Media Pembelajaran Prezi Terhadap Hasil Belajar Siswa Kelas X TPHP Pada Mata Pelajaran Pengendalian Mutu Dalam Proses Pengolahan Di SMK Negeri 3 Takalar," Jurnal Pendidikan Teknologi Pertanian, vol. 3, pp. 42-48, 2017.

[11] N.G. Murray, K.A. Opuni, B. Reininger, N. Sessions, M.M. Mowry, and M. Hobbs, "A Multimedia Educational Program That Increase Science Achievement among Inner-City Non-Asian Minority Middle- School Students," Academic Medicine, vol. 84, pp. 803-811, 2009.

[12] H. Muhammad and D. Priatna, Media Massa dan Masyarakat Modern. Jakarta: Prenada Media, 2004

[13] R.C. Richey, Reflections on the 2008 AECT Definitions of the Field TechTrends, vol. 52, pp. 24-25, 2008.

[14] M. Hasyim, "Pengembangan Multimedia Pembelajaran Statistika Berbasis ICT dengan Model Blended Project Based Learning," Jurnal Cendekia : Jurnal Pendidikan Matematika, vol. 4, pp. 1083-1097, 2020.

[15] S. Malik and A. Agarwal, "Use of Multimedia as a New Educational Technology," Int. Journal of Information and Education Technology, vol. 2, 2012.

[16] G. Krippel, A.J. McKee, and J. Moody, "Multimedia use in higher education: promises and pitfalls," Journal of Instructional Pedagogies, vol. 2, 2010.

[17] G. Friedland, W. Hurst, and L. Knipping, "Educational multimedia systems: the past, the present, and a glimpse into the future," In Proceedings of the international workshop on Educational multimedia and multimedia education, pp. 1-4, 2007

[18] M. Syafiudin, S. Sumarmi, and I.K. Astina, "Pengembangan Modul Geografi Pariwisata dengan Project Based Learning untuk Materi Ekowisata Pesisir dan Laut di Program Studi S1 Pendidikan Geografi Universitas Negeri Malang," Jurnal Pendidikan: Teori, Penelitian, dan Pengembangan, vol. 1, pp. 347-353, 2016. 